\title{
THE EFFECT OF INCLUSION LEVELS OF VITAMIN E AND C ON PERFORMANCE OF BROILER CHICKS FED AFLATOXIN CONTAMINATED DIETS \\ Radwan, A.S. ${ }^{1}$; H. B. A. Gharib ${ }^{2}$; H.F.A. Motawe ${ }^{1}$ and A. M. Atta ${ }^{2}$ \\ ${ }^{1}$ Regional Center for Food and Feed, Agric. Res. Center, Giza, Egypt. \\ ${ }^{2}$ Dept. of Animal Production, Fac. of Agric., Cairo Univ., Giza, Egypt.
}

\begin{abstract}
This experiment was conducted to evaluate the efficiency of using two levels of vitamin $E$ (vit.E) and $C$ (vit.C) either alone or in combination as a feed additive to ameliorate the deleterious effects of Aflatoxin (AF) on broiler performance. A total of 280 one-day old un-sexed Ross broiler chicks were housed in batteries, randomly divided into ten experimental groups as follows: The first group (C) was fed on basal diet (Control), whereas, the rest groups were received the contaminated diet with AF at $1.2 \mathrm{ppm} / \mathrm{kg}$ diet where, $\mathrm{C}^{+}$: fed the contaminated diet, $\mathrm{E}_{100}$ : fed the contaminated diet with $100 \mathrm{mg}$ vit.E/kg diet $\left(E_{1}\right)$, $E_{200}$ : fed the contaminated diet with $200 \mathrm{mg}$ vit.E/ $/ \mathrm{kg}$ diet $\left(E_{2}\right), C_{250}$ : fed the contaminated diet with $250 \mathrm{mg}$ vit.C/ $\mathrm{kg}$ diet $\left(\mathrm{C}_{1}\right), \mathrm{C}_{500}$ : fed the contaminated diet with $500 \mathrm{mg}$ vit.C/kg diet $\left(\mathrm{C}_{2}\right), \mathrm{E}_{100} \mathrm{C}_{250}$ : fed the contaminated diet with $\mathrm{E}_{1}+\mathrm{C}_{1}, \mathrm{E}_{100} \mathrm{C}_{500}$ : fed the contaminated diet with $\mathrm{E}_{1}+\mathrm{C}_{2}, \mathrm{E}_{200} \mathrm{C}_{250}$ : fed the contaminated diet with $E_{2}+C_{1}$ and $E_{200} C_{500}$ : fed the contaminated diet with $E_{2}+C_{2}$. The results indicated that, as expected, that $\mathrm{C}^{+}$group had significantly lower final body weight and total body weight gain; worse total feed conversion ratio and higher total mortality rate than those of the $\mathrm{C}$ group. On the other hand, birds which received contaminated diet with combination of vit. $E$ and vit.C supplementation $\left(\mathrm{E}_{100} \mathrm{C}_{250}\right.$, $\mathrm{E}_{100} \mathrm{C}_{500}, \mathrm{E}_{200} \mathrm{C}_{250}$ and $\mathrm{E}_{200} \mathrm{C}_{500}$ ) had significantly an improvement in productive performance as compared to those received contaminated diet $\left(\mathrm{C}^{+}\right)$. Moreover, there were no significant differences in productive performance among the birds which received control diet and those fed the contaminated diet plus combination of vit.E and $\mathrm{C}$ addition.

Therefore, it could be concluded that supplemental diets with the combination of vit.E and $\mathrm{C}$ can be used as antitoxin when the diet contaminated with aflatoxin.
\end{abstract}

Keywords: Broiler, aflatoxicosis, vitamin E, vitamin C and productive performance.

\section{INTRODUCTION}

Mycotoxins, the secondary metabolites of toxigenic fungi, are unavoidable contaminants in foods and feeds exerting harmful effects upon animal and human health (Zahoor-ul-Hassan et al., 2010). The most important mycotoxins in naturally tainted foods and feeds are aflatoxins, ochratoxins, zearalenone, T-2 toxin, deoxynivalenol and fumonisins (Devegowda et al., 1998; Sultana and Hanif, 2009). Aflatoxins are a group of mycotoxins produced by the strains of Aspergillus flavus and Aspergillus parasiticus (Bennett and Klich, 2003). These fungi can easily contaminate a number of grains causing both important economic losses and health problems. Among the four major groups of aflatoxin namely $B_{1}, B_{2}, G_{1}$ and $\mathrm{G}_{2}$, aflatoxin $\mathrm{B}_{1}\left(A F \mathrm{~B}_{1}\right)$ is the most toxic and a known carcinogenic. Acute or chronic aflatoxicosis in poultry birds results in decreased meat and egg production, immunosuppression and hepatotoxicosis. 
Radwan, A.S. et al.

Numerous strategies, such as physical separation, thermal inactivation, irradiation, microbial degradation and treatment with a variety of chemicals have been used for the detoxification or inactivation of mycotoxincontaminated feedstuff (Goldblatt and Dollear, 1979; Anderson, 1983). Recently, producers, researchers and governments aim to develop effective, inert, cheaper, non-toxic and nutritive prevention management and decontamination technologies to minimize the toxic effects of AF. Several experimental studies have shown that vitamins $C$ and $E$ could ameliorate aflatoxin toxicity (Yu et al., 1994; Salem et al., 2001).Various findings strongly suggested the enhancement of immune response due to vitamin $E$ supplementation (Balker, 1993). At the same time, vitamin C (ascorbic acid) may scavenge peroxyl radical and inhibit cytotoxicity induced by oxidants. In addition, ascorbic acid can reduce or prevent $\mathrm{H}_{2} \mathrm{O}_{2}$-induced lipid peroxidation and the formation of OH-deoxyguanosine (Retsky and Frei, 1995; Tsou et al., 1996). Therefore, the aim of the present study was to evaluate the efficiency of incorporating two levels of vitamin $E$ and $C$ either alone or in their combination to ameliorate the deleterious effects of Aflatoxins (AF) in broiler chick's diet.

\section{MATERIALS AND METHODS}

This experiment was carried out at Regional Center for Food and Feed. A total number of 280 one-day-old straight run broiler Ross chicks was housed in batteries and were randomly divided into ten groups (each of 28 chicks) to receive one of the experimental diets. Each group was divided into four replicates.

\section{Experimental diets:}

C (control)Basal diet (NRC recommended diet without any supplementation).

$\mathrm{C}^{+} \quad$ Contaminated diet with $1.2 \mathrm{ppm}$ aflatoxin $(\mathrm{AF}) / \mathrm{kg}$ diet.

$\mathrm{E}_{100} \quad$ Contaminated diet $+100 \mathrm{mg}$ vit.E $/ \mathrm{kg}$ diet.

$\mathrm{E}_{200} \quad$ Contaminated diet $+200 \mathrm{mg}$ vit. E $/ \mathrm{kg}$ diet.

$\mathrm{C}_{250} \quad$ Contaminated diet $+250 \mathrm{mg}$ vit.C/ $\mathrm{kg}$ diet.

$\mathrm{C}_{500} \quad$ Contaminated diet $+500 \mathrm{mg}$ vit.C $/ \mathrm{kg}$ diet.

$\mathrm{E}_{100} \mathrm{C}_{250} \quad$ Contaminated diet $+100 \mathrm{mg}$ vit. $\mathrm{E}+250 \mathrm{mg}$ vit.C $/ \mathrm{kg}$ diet.

$\mathrm{E}_{100} \mathrm{C}_{500}$ Contaminated diet $+100 \mathrm{mg}$ vit. $\mathrm{E}+500 \mathrm{mg}$ vit.C $/ \mathrm{kg}$ diet.

$\mathrm{E}_{200} \mathrm{C}_{250}$ Contaminated diet $+200 \mathrm{mg}$ vit. $\mathrm{E}+250 \mathrm{mg}$ vit.C $/ \mathrm{kg}$ diet.

$\mathrm{E}_{200} \mathrm{C}_{500}$ Contaminated diet $+200 \mathrm{mg}$ vit. $\mathrm{E}+500 \mathrm{mg}$ vit. $\mathrm{C} / \mathrm{kg}$ diet.

\section{General management:}

Feed and water were provided ad libitum. Diets were formulated in Regional Center for Food and Feed to be isonitrogenous, isocaloric and mycotoxins-free as well as free from any medication as growth promoter or antibiotics. The diets which used were formulated to meet the nutrient requirements of the broiler chicks during starter, grower and finisher periods 
according to the National Research Council (NRC, 1994). All birds were fed a starter diet from one to $14 \mathrm{~d}$ of age containing $22.5 \% \mathrm{CP}$ and $3063 \mathrm{Kcal}$ $\mathrm{ME} / \mathrm{Kg}$ diet. From 15 to $28 \mathrm{~d}$ of age, the birds were switched to grower diet containing $21.5 \% \mathrm{CP}$ and $3144 \mathrm{Kcal} \mathrm{ME} / \mathrm{Kg}$ diet. While, during 29 to $42 \mathrm{~d}$ of age, they were fed finisher diet containing $20.1 \% \mathrm{CP}$ and $3195 \mathrm{Kcal} \mathrm{ME} / \mathrm{Kg}$ diet (Table 1). The temperature was set at $32^{\circ} \mathrm{C}$ on the first day, gradually reduced to $24^{\circ} \mathrm{C}$ by the end of the third week, and until the end of experiment. The light was provided $24 \mathrm{hrs}$ daily throughout the experiment. The averages of initial body weights of different groups were nearly similar. All experimented birds were vaccinated against different diseases according to the vaccination programs adopted in most Egyptian chicken broiler farmers.

Table 1. Composition and calculated analysis of the experimental diets

\begin{tabular}{lccc}
\hline \multicolumn{1}{c}{ Ingredients } & Starter & Grower & Finisher \\
\hline Yellow corn (7.5\% CP) & 56 & 60 & 62.3 \\
Soybean meal (45.8\% CP) & 32 & 25.5 & 24 \\
Corn glutin meal (60.8\% CP) & 5 & 7.5 & 6.5 \\
Vegetable oil & 2.965 & 2.915 & 3.525 \\
Dicalcium phosphate & 1.73 & 1.96 & 1.76 \\
Limestone & 0.81 & 0.56 & 0.56 \\
Vit. \& Min. Mixture (1) & 0.4 & 0.4 & 0.4 \\
Salt & 0.4 & 0.4 & 0.4 \\
L-lysine-HCl & 0.38 & 0.49 & 0.33 \\
DL-Methionine & 0.24 & 0.2 & 0.15 \\
Choline chloride & 0.075 & 0.075 & 0.075 \\
Total & 100 & 100 & 100 \\
Calculated values & & & \\
CP & 22.5 & 21.5 & 20.1 \\
ME (KCal / kg) & 3063 & 3144 & 3195 \\
Lysine & 1.36 & 1.3 & 1.13 \\
Methionine & 0.61 & 0.58 & 0.51 \\
Methionine + Cystine & 0.98 & 0.94 & 0.85 \\
Calcium & 0.96 & 0.9 & 0.85 \\
Available ph & 0.45 & 0.48 & 0.44 \\
\hline (1)Vitamins - ming
\end{tabular}

(1)Vitamins - minerals mixture supplied per kg of diet: vit. (A), 12000 I.U., vit. $\left(D_{3}\right), 2000$ I.U; vit. $(E), 10 \mathrm{mg}$; vit. $\left(K_{3}\right), 2 \mathrm{mg}$; vit. $\left(B_{1}\right), 1 \mathrm{mg}$; vit. $\left(B_{2}\right), 5 \mathrm{mg}$; vit. $\left(B_{6}\right), 1.5 \mathrm{mg}$; vit. $\left(B_{12}\right), 10$

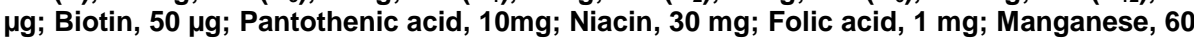
mg; Zinc, 50 mg; Iron, 30 mg; Copper, 10 mg; lodine, 1 mg; Selenium, 0.1 mg and Cobalt, $0.1 \mathrm{mg}$.

\section{Aflatoxin production and assessment:}

Aflatoxin production was carried out according to Davis et al. (1966) using liquid yeast medium and Aspergillus flavus NRRL (3145). The media which contain detectable amount of aflatoxin was mixed well with the basal diet to get the aflatoxin- contaminated diet. Aflatoxin in liquid medium and diet was determined according to Ross et al. (1997) and A.O.A.C (2005) using HPLC technique (Agillent 1100 series USA with column C 18, Lichrospher 100RP- 18, $5 \mu \mathrm{m} \times 25 \mathrm{~cm}$ ). Aflatoxin was incorporated into small portion of the basal diet manually, and then this small portion was mixed with larger 
Radwan, A.S. et al.

amount of basal diet until reaching the desired level of $1200 \mathrm{ppb} \mathrm{AF/kg}$ final feed.

Measured parameters:

Chick's performance response variables were determined according to North (1984); weekly individually body weight (wt.) and wt. gain were measured on all birds. Weekly feed consumption $(\mathrm{g} / \mathrm{d} / \mathrm{bird})$, feed conversion ratio (FCR) ( $\mathrm{g}$ feed/g live body wt. gain) and mortality rate were measured for each replicate. Dead birds were weighed to include their weights in the feed conversion estimation.

\section{Statistical analyses:}

One-way analysis of variance has been adopted using SAS software general linear model (SAS, 2004). The main factor was vitamins supplementation. Mean values were compared using the Duncan's New Multiple Range test (Duncan, 1955) when significant differences existed. Mortality rate was tested by the chi-square procedure (Snedecor and Cochran, 1993). The fixed effects model used in the analysis was as follow:

$Y_{i j}=\mu+T_{i}+e_{i j k}$.

Where:

$Y_{i j:}$ the observation of the $J^{\text {th }}$ chick in the $\mathrm{i}^{\text {th }}$ treatment.

$\mu$ : the overall mean.

$T_{i}$ : effect of the $i^{\text {th }}$ treatment $(i=1,2 \ldots 10)$.

$e_{i j k}$ : the random error effect.

\section{RESULTS AND DISCUSSION}

\section{Body weight (BW):}

Results in Table (2) showed that the body weight of AF-group ( $\mathrm{C}^{+}$ group) in all experimental periods was significantly $(p<0.0001)$ the lowest as compared to the other experimental groups. On the other hand, all vitamins treatments improved the body weight especially of those which received the mixture of vit. $E$ and vit.C. Moreover, at 14 days of age, $\mathrm{E}_{100} \mathrm{C}_{250}$ and $\mathrm{E}_{200} \mathrm{C}_{250}$ groups had the highest $(p<0.0001)$ body weight. Also, at 28 days of age, $E_{100}$, $\mathrm{C}_{500}, \mathrm{E}_{100} \mathrm{C}_{250}, \mathrm{E}_{100} \mathrm{C}_{500}$ and $\mathrm{E}_{200} \mathrm{C}_{500}$ groups had the significantly $(\mathrm{p}<0.0001)$ highest body weight. While, at 42 days of age, $\mathrm{E}_{100} \mathrm{C}_{250}$ and $\mathrm{E}_{100} \mathrm{C}_{500}$ groups had the significantly $(p<0.0001)$ highest body weight.

The decrease in the body weight due to aflatoxicosis in the present study was in agreement with several previous investigations using dietary AF in poultry feed (Salem et al., 2001; Tedesco et al., 2004; Han et al., 2008; Khan et al., 2010).

The decrease of body weight due to aflatoxicosis may be attributed to the biotransformation of aflatoxins which gives rise to various metabolites; the $\mathrm{AFB}_{1}-8,9$-epoxide, in particular, is relevant because it may covalently bind to DNA and to proteins which then alters enzymatic processes such as gluconeogenesis, Krebs cycle or fatty acid synthesis (Lesson et al., 1995) and inhibit the protein synthesis (Oguz et al., 2000a).

The improvement in body weight due to vitamins supplementation to the contaminated feed in the present study was in agreement with several 
attributed to the same reasons of the decrease in body weight. The improvement in body weight gain due to vitamins supplementation to the contaminated feed in the present study was in agreement with results recorded by Shlig (2009).

Table 3. Effects of vit. E and $C$ supplementation on weight gain (g) of broilers fed aflatoxicosis diet

\begin{tabular}{|c|c|c|c|c|}
\hline \multirow{3}{*}{ Treatment } & \multicolumn{4}{|c|}{ Age (day) } \\
\hline & 0-14 days & 15-28 days & 29-42 days & $0-42$ days \\
\hline & $x^{-} \pm S E$ & $x^{-} \pm S E$ & $x^{-} \pm S E$ & $\mathrm{X}^{ - \pm S E}$ \\
\hline $\bar{C}$ & $46.23 \pm 16.58^{b c}$ & $801.92 \pm 35.53^{c}$ & $1269.00 \pm 37.84^{a}$ & $.11^{\mathrm{abc}}$ \\
\hline $\mathrm{C}^{+}$ & & $765.26 \pm 38.31^{c}$ & $1142.78 \pm$ & \\
\hline 100 & $53.57 \pm 16.22^{\mathrm{ab}}$ & $916.19 \pm 19.21^{a}$ & $1201.91 \pm 35.58^{a b c}$ & ${ }^{c} 2371.67 \pm 30.96^{a b}$ \\
\hline $\mathrm{E}_{20}$ & $15.67 \pm 13.20^{\mathrm{cd}}$ & $776.33 \pm 20.85^{c}$ & $1235.50 \pm 29.68^{a b}$ & $2227.50 \pm$ \\
\hline $\mathrm{C}_{25}$ & $4.10^{\mathrm{ab}}$ & $825.72 \pm 19.48^{b c}$ & $1084.17 \pm 27.87^{c d}$ & $2182.02 \pm 25.14^{\mathrm{de}}$ \\
\hline $\mathrm{C}_{5}$ & $244.05 \pm 13.35^{b c}$ & $916.79 \pm 19.57^{a}$ & $1059.17 \pm 54.64^{d}$ & $2220.00 \pm 56$ \\
\hline & 280.6 & $896.79 \pm 34.91^{a b}$ & $1218.10 \pm 79.47^{a b c}$ & c $2395.48 \pm 40$ \\
\hline & 271. & $910.36 \pm 21.96^{a}$ & $1213.45 \pm 40.47^{a b c}$ & c $2395.24 \pm 46.39^{a}$ \\
\hline & 280.2 & $842.14 \pm 30.40^{a b c}$ & $1153.58 \pm 35.04^{\mathrm{abc}}$ & $2275.97 \pm 19.7$ \\
\hline & $259.17 \pm 10.49^{a b}$ & $921.80 \pm 19.73^{a}$ & $1093.68 \pm 15.92^{\mathrm{bcc}}$ & d $2274.64 \pm 41.92^{\mathrm{bcd}}$ \\
\hline & & th different $s$ & 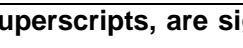 & $\overline{\text { ent }}$ \\
\hline t. & Control & $250 \mathrm{~m}$ & $/ \mathbf{k g}$ diet & $E_{2}$ \\
\hline
\end{tabular}

\section{Feed consumption (FC):}

Results in Table (4) showed that feed consumption through the first 14 days of age was significantly $(p<0.001)$ higher of all experimental groups compared with control group. But, from 15 to 28 days of age, there were no significant differences among groups. While, from 29 to 42 days of age, feed consumption of all groups of vitamin $E$ and vitamin $C$ (either alone or in combination) were significantly $(p<0.001)$ decreased compared with $\mathrm{C}^{+}$ group. Whereas, from 0 to 42 days of age, $E_{100} C_{250}, E_{200} C_{250}$ and $E_{200} C_{500}$ groups addition to control group had the lowest $(p<0.05)$ feed consumption.

The increase or no alteration in feed consumption due to aflatoxicosis in the present study was in agreement with several previous investigations in broiler chicks (Oguz et al., 2000b; Celik et al., 2005; LI Juan-juan et al., 2010). At the same time, these results were in agreement with results reported by Tedesco et al. (2004), who found no alteration in feed consumption of birds fed on diet contaminated by $0.8 \mathrm{ppm} \mathrm{AFB} 1 / \mathrm{kg}$ diet as compared to control birds at the first three weeks of experiment. Whereas, the results disagreed with the results which recorded by Salem et al. (2001); Safameher and Shivazad (2007), they found decrease of feed consumption rate in aflatoxicosis poultry. The differences of results may be attributed to variation of species, age and type of aflatoxin. 
Radwan, A.S. et al.

Table 5. Effects of vit. E and C supplementation on feed conversion ratio ( $\mathrm{g}$ feed/ $\mathrm{g}$ weight gain) of broilers fed aflatoxicosis diet

\begin{tabular}{|c|c|c|c|c|}
\hline \multirow{3}{*}{ Treatment } & \multicolumn{4}{|c|}{ Age (day) } \\
\hline & 0-14 day & 15-28 day & 29-42 day & 0-42 day \\
\hline & $\mathrm{x}^{-} \pm \mathrm{SE}$ & $x \pm S E$ & $x \pm$ SE & $x^{-} \pm S E$ \\
\hline$\overline{\mathrm{C}}$ & $1.18 \pm 0.08^{c}$ & $1.56 \pm 0.06^{a b}$ & $1.75 \pm 0.08^{b}$ & $1.62 \pm 0.02^{d}$ \\
\hline $\mathrm{C}^{+}$ & $1.55 \pm 0.02^{a}$ & $1.67 \pm 0.18^{a}$ & $2.17 \pm 0.04^{\mathrm{a}}$ & $1.92 \pm 0.07^{a}$ \\
\hline$E_{100}$ & $1.39 \pm 0.05^{\mathrm{ab}}$ & $1.44 \pm 0.04^{\mathrm{ab}}$ & $1.87 \pm 0.04^{b}$ & $1.65 \pm 0.01^{\mathrm{bcd}}$ \\
\hline $\mathrm{E}_{200}$ & $1.54 \pm 0.04^{a}$ & $1.64 \pm 0.03^{a}$ & $1.84 \pm 0.05^{b}$ & $1.74 \pm 0.04^{b c}$ \\
\hline $\mathrm{C}_{250}$ & $1.38 \pm 0.03^{a b}$ & $1.53 \pm 0.03^{a b}$ & $1.97 \pm 0.04^{\mathrm{ab}}$ & $1.73 \pm 0.01^{b c}$ \\
\hline $\mathrm{C}_{500}$ & $1.43 \pm 0.01^{a b}$ & $1.47 \pm 0.06^{a b}$ & $2.12 \pm 0.09^{a}$ & $1.77 \pm 0.02^{b}$ \\
\hline $\mathrm{E}_{100} \mathrm{C}_{250}$ & $1.31 \pm 0.01^{\mathrm{b}}$ & $1.34 \pm 0.02^{\mathrm{ab}}$ & $1.79 \pm 0.12^{b}$ & $1.56 \pm 0.05^{d}$ \\
\hline $\mathrm{E}_{100} \mathrm{C}_{500}$ & $1.35 \pm 0.03^{b}$ & $1.43 \pm 0.05^{a b}$ & $1.79 \pm 0.06^{b}$ & $1.60 \pm 0.04^{d}$ \\
\hline $\mathrm{E}_{200} \mathrm{C}_{250}$ & $1.30 \pm 0.03^{b}$ & $1.49 \pm 0.04^{\mathrm{ab}}$ & $1.82 \pm 0.04^{b}$ & $1.63 \pm 0.03^{\mathrm{cd}}$ \\
\hline $\mathrm{E}_{200} \mathrm{C}_{500}$ & $1.38 \pm 0.11^{\mathrm{ab}}$ & $1.46 \pm 0.05^{\mathrm{ab}}$ & $1.83 \pm 0.04^{b}$ & $1.63 \pm 0.05^{\mathrm{cd}}$ \\
\hline
\end{tabular}

$\mathrm{a}, \mathrm{b}, \mathrm{c}, \mathrm{d}$ Means in the same column, with different superscripts, are significantly different $(p<0.05)$.

$\mathrm{C}=$ Control diet, $\mathrm{C}^{+}=$Control diet+1.2 ppm aflatoxin (AF)/kg diet, $\mathrm{E}_{100}=\mathrm{Control} \operatorname{diet}+\mathrm{AF}+\mathbf{1 0 0}$ $\mathrm{mg}$ vit.E/kg diet, $E_{200}=$ Control diet $+A F+200 \mathrm{mg}$ vit.E/ $\mathrm{kg}$ diet, $C_{250}=$ Control diet $+A F+250 \mathrm{mg}$ vit.C/kg diet, $C_{500}=C o n t r o l$ diet $+A F+500 \mathrm{mg}$ vit. $C / \mathrm{kg}$ diet, $E_{100} C_{250}=$ Control diet $+A F+100 \mathrm{mg}$

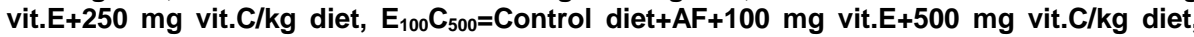
$E_{200} C_{250}=$ Control diet+AF+200 mg vit.E $+250 \mathrm{mg}$ vit.C/kg diet and $E_{200} C_{500}=C o n t r o l$ diet+AF+200 mg vit.E+500 mg vit.C/kg diet.

The inferior feed conversion ratio due to aflatoxicosis in the present study was in agreement with several previous investigations in poultry (Safameher and Shivazad, 2007; Han et al., 2008; Shi et al., 2009). In broiler chicks, the results were in agreement with Shi et al. (2006); Pasha et al. (2007); LI Juan-juan et al. (2010). Also, Our results were in agreement with results of Oguz et al. (2000b) when they fed broiler chicks on contaminated diet by $100 \mathrm{ppb} \mathrm{AF/kg} \mathrm{diet,} \mathrm{and} \mathrm{found} \mathrm{significantly} \mathrm{inferior} \mathrm{FCR} \mathrm{compared} \mathrm{to}$ control group whereas, the results were in disagreement with them when they fed broiler chicks on contaminated diet by $50 \mathrm{ppb} A F / \mathrm{kg}$ diet, they found no notable differences in FCR compared to control group. Also, the results were in disagreement with Tedesco et al. (2004), who reported that feed conversion ratio of commercial broilers (14-d-old and were adapted for five days) was not influenced by fed on $0.8 \mathrm{mg} \mathrm{AFB} / 1 / \mathrm{kg}$ diet for 35 days might be because of increase of age and decrease the duration of exposure to aflatoxin.

The increase of feed conversion ratio in birds which fed on AF contaminated diet may be attributed to anorexia, listlessness, inhibition of protein synthesis and lipogenesis (Kubena et al., 1998; Oguz and Kurtoglu, 2000; Oguz et al., 2000a). Impairing liver functions and protein/lipid utilization mechanisms due to aflatoxicosis may have also affected the growth performance and general health (Espada et al., 1992; Fernandez et al., 1994).

The significant improvement of feed conversion ratio in vitamins groups was in agreement with results obtained by He et al. (2013).

Mortality Rate:

The results in Table (6) showed no significant differences among all experimental groups in mortality rate at 14 and 28 days of age. Whereas, the mortality rate at 42 days of age and total period of $\mathrm{C}^{+}$group was significantly 
the highest as compared to all experimental groups. Moreover, at 42 days of age, $\mathrm{E}_{100}$ and $\mathrm{E}_{100} \mathrm{C}_{250}$ groups had the significantly lowest rate of mortality (did not record any mortality) while, in a cumulative period, $\mathrm{E}_{100} \mathrm{C}_{250}$ group had the significantly lowest rate of mortality.

Table 6. Effects of vit. E and C supplementation on Mortality Rate of broilers fed aflatoxicosis diet

\begin{tabular}{lcccc}
\hline \multirow{2}{*}{ Treatment } & \multicolumn{4}{c}{ Age (day) } \\
\cline { 2 - 5 } & $\mathbf{0 - 1 4}$ days & $\mathbf{1 5 - 2 8}$ days & $\mathbf{2 9 - 4 2}$ days & $\mathbf{0 - 4 2}$ days \\
\cline { 2 - 5 } & $(\%)$ & $(\%)$ & $(\%)$ & $(\%)$ \\
\hline $\mathrm{C}^{+}$ & 3.57 & 3.70 & 3.85 & 10.71 \\
$\mathrm{E}_{100}$ & 10.71 & 4.00 & 25.00 & 35.71 \\
$\mathrm{E}_{200}$ & 7.14 & 3.85 & 0.00 & 10.71 \\
$\mathrm{C}_{250}$ & 7.14 & 3.85 & 4.00 & 14.29 \\
$\mathrm{C}_{500}$ & 0.00 & 0.00 & 7.14 & 7.14 \\
$\mathrm{E}_{100} \mathrm{C}_{250}$ & 10.71 & 4.00 & 8.33 & 21.43 \\
$\mathrm{E}_{100} \mathrm{C}_{500}$ & 3.57 & 0.00 & 0.00 & 3.57 \\
$\mathrm{E}_{200} \mathrm{C}_{250}$ & 0.00 & 3.57 & 3.70 & 7.14 \\
$\mathrm{E}_{200} \mathrm{C}_{500}$ & 10.71 & 0.00 & 8.00 & 17.86 \\
\end{tabular}

No significant difference between treatments in starter period $\left(\chi^{2}=7.57, \mathrm{P}=0.57\right)$

No significant difference between treatments in growing period $\left(\chi^{2}=3.15, P=0.95\right)$

Difference between treatments in finishing period was significant $\left(\chi^{2}=19.20, P=0.02\right)$

Difference between treatments in the entire period was significant $\left(\chi^{2}=17.50, P=0.04\right)$

$\mathrm{C}=$ Control diet, $\mathrm{C}^{+}=$Control diet $+1.2 \mathrm{ppm}$ aflatoxin $(\mathrm{AF}) / \mathrm{kg}$ diet, $\mathrm{E}_{100}=$ Control diet $+\mathrm{AF}+100$ $\mathrm{mg}$ vit. $\mathrm{E} / \mathrm{kg}$ diet, $\mathrm{E}_{200}=$ Control diet $+\mathrm{AF}+200 \mathrm{mg}$ vit. $\mathrm{E} / \mathrm{kg}$ diet, $\mathrm{C}_{250}=$ Control diet $+A F+250 \mathrm{mg}$ vit.C $/ \mathrm{kg}$ diet, $C_{500}=C o n t r o l$ diet $+A F+500 \mathrm{mg}$ vit. $C / \mathrm{kg}$ diet, $E_{100} C_{250}=C$ ontrol diet $+A F+100 \mathrm{mg}$ vit. $E+250 \mathrm{mg}$ vit. $C / \mathrm{kg}$ diet, $E_{100} C_{500}=C o n t r o l ~ d i e t+A F+100 \mathrm{mg}$ vit. $E+500 \mathrm{mg}$ vit. $C / \mathrm{kg}$ diet, $E_{200} C_{250}=$ Control diet $+A F+200 \mathrm{mg}$ vit. $E+250 \mathrm{mg}$ vit.C/kg diet and $E_{200} C_{500}=$ Control diet+AF+200 mg vit.E+500 mg vit.C/kg diet.

The increase in mortality rate due to aflatoxicosis at 42 days of age and in the entire period of experiment of this study was in agreement with that reported by Pasha et al. (2007). The increase of mortality rate due to aflatoxicosis at 42 days of age and in the entire period of experiment of this study may be attributed to reducing disease resistance, the gradually increase of chronic toxic effects (Oguz et al., 2000b), or, severely inhibiting the immune system of the birds (Pasha et al., 2007). While, the results obtained were in disagreement with the results of Oguz et al. (2000b) and Tedesco et al. (2004). This disagreement may be due to the variation of age, dose, sex, duration of exposure and immune response.

The significant decrease in mortality rate due to vitamins supplementation, in the present study, was in agreement with previous investigations in broiler chicks fed mycotoxins contaminated diets with vitamin E or C (Mubarak et al., 2009; El Barkouky et al., 2010).

In the present study the improvement in productive performance due to vitamins supplementation to the contaminated feed may be attributed to that vitamin $E$ ( $\alpha$-tocopherol) has long been recognized as being the major lipid-soluble and chain breaking antioxidant that prevents free radicals from initiating peroxidative tissue damage (Verma et al., 2007). Several studies have also shown that $\alpha$-tocopherol inhibits free radical formation (Kalender et al., 2004; Kalender et al., 2005) and may effectively minimize lipid 
peroxidation in biological systems (Kalender et al., 2002).Vitamin $\mathrm{E}$ is known for its antioxidant properties and has been shown to modulate immune functions in various species (Konjufca et al., 2004). Vitamin C (ascorbic acid) is a well-known low molecular weight antioxidant that protects the cellular compartment from water-soluble oxygen and nitrogen radicals (Jurczuk et al., 2007). Vitamin C efficiently inhibits in vitro lipid peroxidation due to a combination of direct radical interception and interaction with a-tocopherol as a co-antioxidant (Verma et al., 2007). Kultu, (2001) reported that ascorbic acid supplementation increased body weight gain, carcass weight and concluded that ascorbic acid supplementation improved the productive performance of broiler chicks with experimentally induced hypothyroidism. The beneficial influences of ascorbic acid (AA) noted in the present study can be attributed to the fact that AA is a very efficient antioxidant, and a scavenger of oxygen free radicals, which are toxic by-products of many metabolic processes (Dawson et al., 1990). Also, Ascorbic acid was reported to inhibit the binding of $A F B_{1}$ to DNA (Yu et al., 1994). In addition, AA is required for the hydroxylation of essential amino acids and of several oxidase enzymes (Tucker and Halver, 1984; Dawson et al., 1990).

\section{CONCLUSION}

The present results indicated that, aflatoxin is one of the most potent important mycotoxins in broilers due to its toxicity. Aflatoxin produces large deleterious and negative effects on broiler's productive performance. The addition of vit. $E$ and vit. $C$ in combination form may be efficient in reducing the negative effects of aflatoxin and enhance broiler's tolerance to toxicity. However, results showed that addition of combination of vit.E and vit.C at 100 $\mathrm{mg} / \mathrm{kg}$ and $250 \mathrm{mg} / \mathrm{kg}$ aflatoxin contaminated diet, respectively, was more efficient in reducing the negative effects of aflatoxin on broiler's productive performance.

\section{REFERENCES}

Anderson, R.A. (1983). Detoxification of aflatoxin contaminated corn. In: Diener, U., Asquith, R., Dickens, J.(Eds.), Aflatoxin and Aspergillus flavus in Corn. Southern Cooperative Series Bulletin 279. Auburn University, Auburn, AL, pp. 87-90.

AOAC (2005). Association of Official Analytical Chemists of Official Methods of Analysis. $18^{\text {th }}$ ed,. Washington. D. C.

Balker, S. (1993). Role of vitamin $E$ in enhancing in immune response. Proceeding of 2nd Asian /Pacific poultry health, Australia.

Bennett, J.W. and Klich, M. (2003). Mycotoxins. Clinical Microbiology Reviews 16, 497-516.

Celik, S.; Erdogan, Z.; Erdogan, S. and Bal, R. (2005). Efficacy of Tribasic Copper Chloride (TBCC) to Reduce the Harmful Effects of Aflatoxin in Broilers. Turk. J. Vet. Anim. Sci., 29:909-916.

Davis, N.D.; Dionber, U.L. and Dridge, D.W. (1966). Production of Aflatoxin $B_{1}$ and $G_{1}$ by Aspergillus flavous in a semisynthetic medium, Applied Microbiology, 14, 378-380. 
Dawson, E.B., Harris, W.A., Powell, L.C. (1990). Relationship between ascorbic acid and male fertility. World Rev. Nutr. Diet. 62, 1-26.

Devegowda, G.; Raju, M.V.L.N. and Swamy, H.V.L.N. (1998). Mycotoxins: Novel solutions for their counteraction. Feedstuffs 70, 12-17.

Duncan, D. B. (1955). The Multiple Ranges and multiple F-Tests. Biometrics, 11:1-42.

El Barkouky, E. M.; Mohamed, F. R.; Atta, A. M.; Abu Taleb, A. M.; ElMenawey, M. A. and Hatab, M. H. (2010). Effect of Saccharomyces Cerevisiae and Vitamin C Supplementation on Performance of Broilers Subjected to Ochratoxin A Contamination. Egypt. Poult. Sci., 30 (I): 89113.

Espada, Y.; Domingo, M.; Gomez, J. and Calvo, M.A. (1992). Pathological lesions following an experimental intoxication with aflatoxin $B_{1}$ in broiler chickens. Research in Veterinary Science 53, 275-279.

Fernandez, A.; Verde, M.; Gascon, M.; Ramos, J.; Gomez, J.; Luco, D.F. and Chavez, G. (1994). Variations of clinical, biochemical parameters of laying hens and broiler chickens fed flatoxin-containing feed. Avian Pathology 23, 37-47.

Goldblatt, L.A. and Dollear, F.G. (1979). Modifying mycotoxin contamination in feed-use of mold inhibitors, ammoniation, roasting. In: Interactions of Mycotoxins in animal production. National Academy of Science,Washington, DC, pp. 167-184.

Han, Xin-Yan; Huang, Qi-Chun; Li, Wei-Fen; Jiang, Jun-Fang and Xu, ZiRong. (2008). Changes in Growth Performance, Digestive Enzyme Activities and Nutrient Digestibility of Cherry Valley Ducks in Response to Aflatoxin $B_{1}$ Levels. Livestock Science, 119:216-220.

He, J.; K.Y.Zhang, K.Y.; Chen, D.W.; Ding, X.M.; Feng, G.D. and Aoc, X. (2013). Effects of vitamin $E$ and selenium yeast on growth performance and immune function in ducks fed maize naturally contaminated with aflatoxinB ${ }_{1}$ Livestock Science. journal homepage: www.elsevier.com/locate/livsci.

Jurczuk, M.; Brzóska, M.M. and Moniuszko-Jakoniuk, J. (2007). Hepatic and renal concentrations of vitamins $E$ and $C$ in lead- and ethanol-exposed rats. An assessmen of their involvement in the mechanisms of peroxidative damage. Food Chem. Toxicol, 45, 1478-1486.

Kalender, S.; Kalender, Y.; Ates, A.; Yel, M.; Olcay, E. and Candan, S. (2002). Protective role of antioxidant vitamin $E$ and catechin on idarubicin-induced cardiotoxicity in rats. Braz. J. Med. Biol. Res, 35, 1379-1387.

Kalender, S.; Kalender, Y.; Ogutcu, A.; Uzunhisarcikli, M.; Durak, D. and Acikgoz, F. (2004). Endosulfan-induced cardiotoxicity and free radical metabolism in rats: the protective effect of vitamin E. Toxicology, 202, 227-235.

Kalender, Y.; Yel, M. and Kalender, S. (2005). Doxorubicin hepatotoxicity and hepatic free radical metabolism in rats. The effects of vitamin $E$ and catechin. Toxicology, (209):39-45. 
Khan, W.A.M.; Zargham, Khan; Ahrar, Khan and Iftikhar, Hussain. (2010). Pathological Effects of Aflatoxin and Their Amelioration by Vitamin E in White Leghorn Layers. Pak Vet J, 30(3): 155-162.

Konjufca, V.K., Bottje, W.G., Bersi, T.K., Erf, G.F. (2004). Influence of dietary vitamin $E$ on phagocytic functions of macrophages in broilers. Poult. Sci., 83, 1530-1534.

Kubena, L.F.; Harvey, R.B.; Bailey, R.H.; Buckley, S.A. and Rottinghaus, G.E. (1998). Effects of a hydrated sodium calcium aluminosilicate (TBind) on mycotoxicosis in young broiler chickens. Poultry Sci., 77: 1502-1509.

Kultu, H. R. (2001). Influences of wet feeding and supplementing with ascorbic acid on performance and carcass composition of broiler chicks exposed to high ambient temperature. Arch. Tierernahr, 54 (2):127-139

Kumar, P. Anil.; Satyanarayana, M. L. and Vijayasarathi, S. K. (2003). Pathology of Lymphoid Organs in Aflatoxicosis and Ochratoxicosis and Immunomodulatory Effect of Vitamin E and Selenium in Broiler Chicken. Indian Journal of Veterinary Pathology, 27 (2): 102-106.

Lesson, S.; Diaz, G. and Summers, J.D. (1995). Aflatoxins. In: Poultry Metabolic Disorders and Mycotoxins. Eds. S. Lesson, G. Diaz, J.D. Summers, Ontario, Canada: University Books, pp. 249-298.

LI Juan-juan, SUO De-cheng and SU Xiao-ou. (2010). Binding Capacity for Aflatoxin $B_{1}$ by Different Adsorbents. Agricultural Sciences in China, 9(3): 449-456.

Mubarak, A.; Rashid, A.; Khan, I. A. and Hussain, A. (2009). Effect of Vitamin $\mathrm{E}$ and Selenium as Immunomodulators on Induced Aflatoxicosis in Broiler Birds. Pak. j. life soc. sci., 7 (1): 31-34.

National Research Council. (1994). Nutrient requirements of poultry. 9th rev. ed. National Academic Press, Washington, DC.

North, M. O. (1984). Broiler, roaster, and capon management Chapter 20, P.387. in "commercial chicken production manual". $3^{\text {rd }}$ edition. By The AVI publishing Company Inc. West Port Connecticut.

Oguz, H. and Kurtoglu, V. (2000) Effect of clinoptilolite on fattening performance of broiler chickens during experimental aflatoxicosis. British Poultry Science, (41) 512-517.

Oguz, H.; Kececi, T.; Birdane, Y.O.; Onder, F. and Kurtoglu, V. (2000a). Effect of clinoptilolite on serum biochemical and haematological characters of broiler chickens during experimental aflatoxicosis. Research in Veterinary Science, (69) 89-93.

Oguz, H.; Kurtoglu, V. and Coskun, B. (2000b). Preventive efficacy of clinoptilolite in broilers during chronic aflatoxin (50 and $100 \mathrm{ppb}$ ) exposure. Research in Veterinary Science, (69) 197-201.

Parlat, S.; Ozcan, M. and Oguz, H. (2001). Biological suppression of aflatoxicosis in Japanese quail (Coturnix coturnix japonica) by dietary addition of yeast (Saccharomyces cerevisiae). Research in Veterinary Science, ISSN 0034-5288 71(3):207-211.

Pasha, T. N.; Farooq, M. U.; Khattak, F. M.; Jabbar, M. A. and Khan, A. D. (2007). Effectiveness of Sodium Bentonite and Two Commercial 
Products as Aflatoxin Absorbents in Diets for Broiler Chickens. Animal Feed Science and Technology, (132): 103-110.

Retsky, K. L., \& Frei, B. (1995). Vitamin C prevents metal iondependent initiation and propagation of lipid peroxidation in human low-density lipoprotein. Biochimica et Biophysica Acta, 1257, 279-287.

Richardson, K.E. and Hamilton, P.B. (1987). Enhanced production of pancreatic digestive enzymes during aflatoxicosis in egg-type chickens. Poult. Sci., (66): 1470-1478.

Ross, A. H.; H. J. and Van der Kamp Marley, E.C. (1997). Comparison of immunune affinity columns for the determination of aflatoxin in animal feed maize. Mycotoxin Research, (13): 1-10.

Safameher, A. and Shivazad, M. (2007). The Effects of Saccharomyces cerevisiae on Performance and Biochemical Parameters in Broiler Chicks During Aflatoxicosis. Journal of Animal and veterinary advances, 6 (8): 917-919.

Salem, M.H.; Kamel, K.I.; Yousef, M.I.; Hassan, G.A. and EL-Nouty, F.D. (2001). Protective Role of Ascorbic Acid to Enhance Semen Quality of Rabbits Treated With Sublethal Doses of Aflatoxin B1. Toxicology, (162): 209-218.

SAS, (2004). SAS User's Guide: Statistics. Version 9.1. SAS Inst. Inc., Cary, NC., USA.

Shi, Y.H.; Xu, Z.R.; Feng, J.L. and Wang, C.Z. (2006). Efficacy of Modified Montmorillonite Nanocomposite to Reduce the Toxicity of Aflatoxin in Broiler Chicks. Animal Feed Science and Technology, 129: 138-148.

Shi, Y.H.; Xu, Z.R.; Sun, Y.; Wang, C.Z. and Feng, J. (2009). Effects of Two Different Types of Montmorillonite on Growth Performance and Serum Profiles of Broiler Chicks during Aflatoxicosis. Turk. J. Vet. Anim. Sci., 33(1): 15-20.

Shlig, A.A. (2009). Effect of Vitamin E and Selenium Supplement in Reducing Aflatoxicosis on Performance and Blood parameters in Broiler Chicks. Iraqi Journal of Veterinary Sciences, 23 (I): 97-103.

Snedecor, G.W. and Cochran, W.G. (1993). Statistical methods ISBN: 08138-1561-4

Sultana, N. and Hanif, N.Q. (2009). Mycotoxin contamination in cattle feed and feed ingredients. Pak. Vet. J., (29): 211-213.

Tedesco, D.; Steidler, S.; Galletti, S.; Tameni, M.; Sonzogni, O. and Ravarotto, L. (2004). Efficacy of Silymarin-Phospholipid Complex in Reducing The Toxicity of Aflatoxin $B_{1}$ in Broiler Chicks. Journal of Poultry Science, (83): 1839-1843.

Tsou, T. C., Chen, C. L., Liu, T. Y., and Yang, J. L. (1996). Induction of 8hydrodehydroxyguanosine in DNA by chromium (III) plus hydrogen peroxide and its prevention by scavengers. Carcinogenesis.

Tucker, B.W. and Halver, J.E. (1984). Ascorbate-2-sulfate metabolism in fish. Nutr. Rev., 42, 173-179.

Verma, R.S.; Mehta, A. and Srivastava, N. (2007). In vivo chlorpyrifos induced oxidative stress: attenuation by antioxidant vitamins. Pestic. Biochem. Phys., (88):191-196. 


\section{Radwan, A.S. et al.}

Yu, M.W.; Zhang, Y.J.; Blaner, W.S. and Santella, R.M. (1994). Influence of vitamins $A, C$ and $E$ and $\beta$-carotene on aflatoxin $B_{1}$ binding to DNA in woodchuck hepatocytes. Cancer, (73):596-604.

Zaghini, A.; Martelli, G.; Roncada, P.; Simioli, M. and Rizzi, L. (2005). Mannanoligosaccharides and Aflatoxin $B_{1}$ in Feed for Laying Hens: Effects on Egg Quality, Aflatoxins $B_{1}$ and $M_{1}$ Residues in Eggs, and Aflatoxin $B_{1}$ Levels in Liver. Poultry Science, (84): 825-832.

Zahoor-ul-Hassan, Khan, M.Z., Khan, A., Javed, I., (2010). Pathological responses of White Leghorn breeder hens kept on ochratoxin a contaminated feed. Pak. Vet J. (30): 118-123.

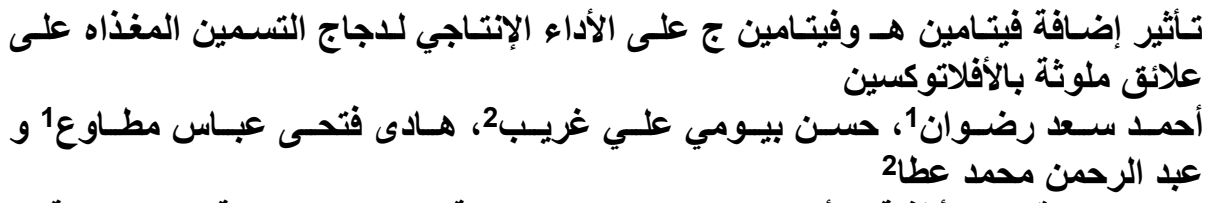

1. المركز الإقليمي للأغذية والأعلاف، مركز البحوث الزراعية، الجيزة، جمهورية مصر العربية.

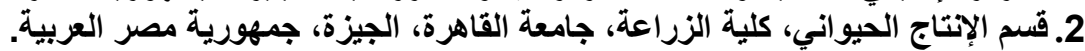

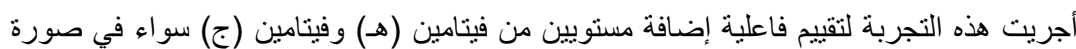

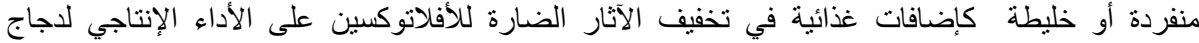

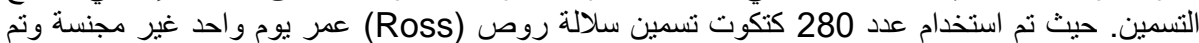

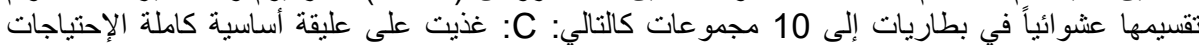

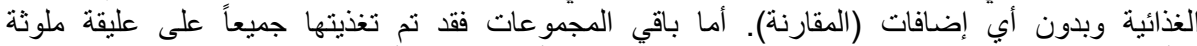

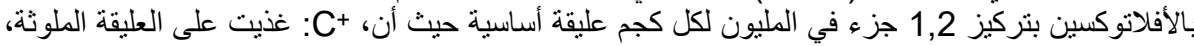

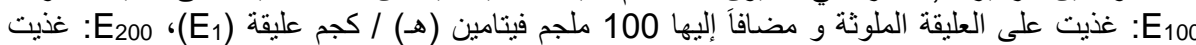

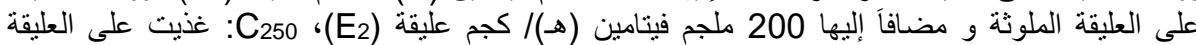

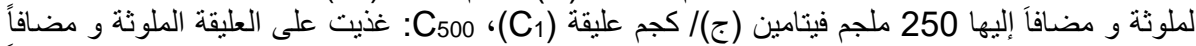

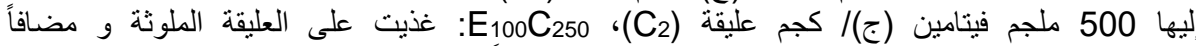
إليها [ الئاس

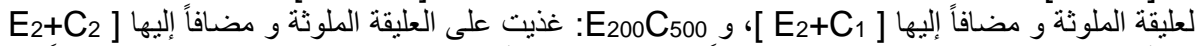

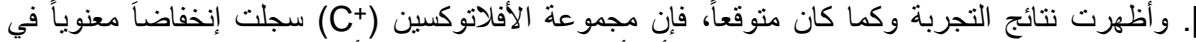

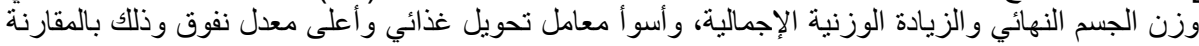

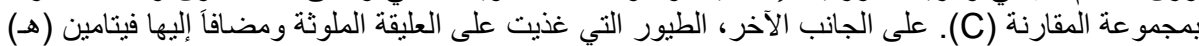
وفيتامين (ج) في الصورة الخليطة (C)

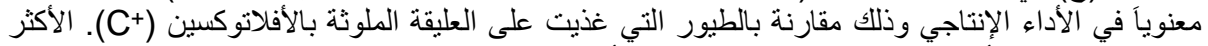

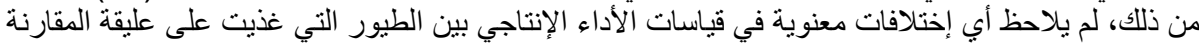

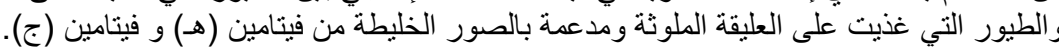

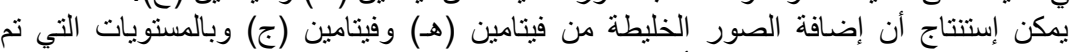

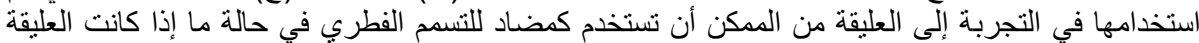

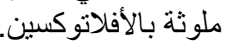

كلية الزراعة - جامعة المنصورة المركز القومى للبحوث المنهور
قام بتحكيم البحث

أ.د / إندمد محمد البحث الثناوى

أ. أد / محسن محمود شكرى الشناوى 